\title{
Breastfeeding inequities in South Africa: Can enforcement of the WHO Code help address them? - A systematic scoping review
}

Debbie Vitalis $^{1 *}\left(\mathbb{D}\right.$, Mireya Vilar-Compte ${ }^{1}$, Kate Nyhan $^{2}$ and Rafael Pérez-Escamilla ${ }^{1}$

\begin{abstract}
Introduction: Suboptimal breastfeeding rates in South Africa have been attributed to the relatively easy access that women and families have had to infant formula, in part as a result of programs to prevent maternal-to-child transmission (MTCT) of HIV. This policy may have had an undesirable spill-over effect on HIV-negative women as well. Thus, the aims of this scoping review were to: (a) describe EBF practices in South Africa, (b) determine how EBF has been affected by the WHO HIV infant feeding policies followed since 2006, and (c) assess if the renewed interest in The Code has had any impact on breastfeeding practices in South Africa.

Methods: We applied the Joanna Briggs Institute guidelines for scoping reviews and reported our work in compliance with the PRISMA Extension (PRISMA-SCR). Twelve databases and platforms were searched. We included all study designs (no language restrictions) from South Africa published between 2006 and 2020. Eligible participants were women in South Africa who delivered a healthy live newborn who was between birth and 24 months of age at the time of study, and with known infant feeding practices.

Results: A total of 5431 citations were retrieved. Duplicates were removed in EndNote and by Covidence. Of the 1588 unique records processed in Covidence, 179 records met the criteria for full-text screening and 83 were included in the review. It was common for HIV-positive women who initiated breastfeeding to stop doing so prior to 6 months after birth (1-3 months). EBF rates rapidly declined after birth. School and work commitments were also reasons for discontinuation of EBF. HIV-positive women expressed fear of HIV MTCT transmission as a reason for not breastfeeding.

Conclusion: The Review found that while enforcing the most recent WHO HIV infant feeding guidelines and the WHO Code may be necessary to improve breastfeeding outcomes in South Africa, they may not be sufficient because there are additional barriers that impact breastfeeding outcomes. Mixed-methods research, including indepth interviews with key informants representing different government sectors and civil society is needed to prioritize actions and strategies to improve breastfeeding outcomes in South Africa.
\end{abstract}

Keywords: Breastfeeding, The WHO code for Marketing of Breastmilk Substitutes, HIV, Infant feeding, Infant feeding guidelines, South Africa

\footnotetext{
* Correspondence: debbie.vitalis@yale.edu

${ }^{1}$ Yale University School of Public Health, New Haven, CT 06510, USA

Full list of author information is available at the end of the article
} 
This article is a part of the Interventions and policy approaches to promote equity in breastfeeding collection, guest-edited by Rafael Pérez-Escamilla, PhD and Mireya Vilar-Compte, PhD

\section{Introduction}

In 2016, South Africa recorded 67.3\% of infants initiating breastfeeding within $1 \mathrm{~h}$ of birth, and only $31.6 \%$ being exclusively breastfed, with a mean exclusive breastfeeding duration of 2.9 months [1], the lowest rates on the African continent [2]. South Africa, an upper-middle income country in Sub-Saharan Africa has a population of about 58 million $[3,4]$. While South Africa is rich in natural resources, its social indices reflect structural vulnerabilities and inequities, such as healthcare gaps and the uneven impact of HIV/AIDS [5]. South Africa's maternal mortality ratio is $119 / 100,000$ live births [6], and child mortality rates have been steadily declining with infant and under- 5 mortality rates of 28 and 35 per 1000 live births compared to Sub-Saharan Africa's rates of 52 and 76 respectively $[7,8]$.

Breastfeeding is vital for an infant's development and survival as it reduces morbidity and mortality from diarrhea, pneumonia and malnutrition, particularly in infants under-5 years [9-11]. Breastfeeding also reduces the risk of childhood obesity and fosters cognitive development [10, 12-14]. Furthermore, it confers health benefits to mothers including reduced risk of cancers (breast, ovarian), hypertension and diabetes [10, 15, 16].

The World Health Organization (WHO) and the United Nations Children's Fund (UNICEF) recommend exclusive breastfeeding (EBF) of infants from birth to 6 months, followed by the introduction of nutritious and safe complementary foods with continued breastfeeding for at least 2 years [9]. The United Nations (UN) policy brief on The UN Decade of Action on Nutrition includes five targets to eradicate all types of malnutrition, as well as six targets to improve maternal, child health and nutrition by 2025 [17]. Target 5 on breastfeeding, aims to increase exclusive EBF rates to at least $50 \%$ by 2025 [17]. Hence, it is of concern that globally just $44 \%$ of infants are breastfed soon after birth, and $40 \%$ of those less than 6 months old are exclusively breastfed $[9,18]$. In 1985, HIV infection through human milk or breastfeeding was first recognized in the United States $[19,20]$ and the Centers for Disease Control and Prevention issued guidelines for HIV-positive women to adopt replacement feeding [21].

In terms of HIV-positive women, WHO guidelines on infant feeding have drastically evolved over time. Initially in 2001, the WHO advised women not to breastfeed when affordable and safe human milk substitutes were available due to evidence supporting the mother to child transmission (MTCT) of HIV through human milk or breastfeeding [22]. By 2006, WHO advised that early cessation of breastfeeding before 6 months was no longer required for HIV-positive women [23]. In 2010, they advised women on anti-retroviral treatment (ART) to exclusively breastfeed for 6 months and continue breastfeeding for 1 year [10, 24]. Finally in 2016, the timeline for breastfeeding was extended to at least 24 months, and mixed feeding was no longer considered a risk factor for MTCT as long as ART was available [9].

In 2011, South Africa changed its infant feeding policy to EBF for all women regardless of HIV status [25]. This shift in policy conveyed through the Tshwane declaration was aligned with WHOs 2010 guidelines on HIV and infant feeding that realigned breastfeeding guidelines of HIV-positive women with HIV-negative women as long as ARTs are available $[25,26]$. The declaration also called for not distributing free infant formula for HIV-positive women (except for medical reasons) at public health facilities, and for these facilities to become "baby-friendly" by $2015[18,25]$.

The UNICEF/WHO Baby Friendly Hospital Initiative (BFHI) launched in 1991 was designed to strengthen the capacity of maternity facilities to protect, promote, and support successful breastfeeding [27]. The Tshwane declaration also called for the government to establish legislation to enforce the WHO International Code on Marketing of Breast Milk substitutes (The Code) [25]. The Code includes specific guidelines to protect, promote and support breastfeeding by regulating the advertising and sales of breastmilk substitutes (BMS), bottles and teats [28, 29].

While The Code was approved since 1981 by the World Health Assembly [29] violations continue to be widespread globally due to weak Code monitoring and enforcement mechanisms across countries, especially in low-to-middle income countries (LMIC) [30-32]. As a result, infant formula sales have increased exponentially in LMICs, including in South Africa resulting in higher rates of morbidity and mortality [30, 31, 33, 34].

South Africa also has one of the highest rates of HIV in the world with an adult prevalence of 19.2\% [4]. Breastfeeding outcomes are suboptimal in South Africa $[11,33,35]$. Some have attributed it, at least in part, to the relatively easy access that women and families have had to infant formula as a result of infant formula distribution programs designed to prevent MTCT of HIV [36]. Apparently, this policy may have had an undesirable spill-over effect on HIV-negative women as well. Hence, South African academics and advocates have called for enforcing The Code within the framework of the most recent WHO guidelines on infant feeding in the context of HIV $[9,33]$. Enforcing The Code is paramount in the context of WHOs most recent guidelines on infant feeding [9] to improve EBF. Thus, the 
aims of this scoping review were to: (a) describe EBF practices in South Africa, (b) determine how EBF has been affected by the HIV infant feeding policies followed since 2006, and (c) assess if the renewed interest in The Code has had any impact on breastfeeding practices in South Africa.

\section{Methods and analyses}

We applied the PRISMA Extension (PRISMA-ScR) and Joanna Briggs Institute guidelines for scoping reviews $[37,38]$. The review protocol was registered in Open Science Framework (OSF) (https://osf.io/ sxcfv/). A highly experienced medical librarian (KN) conducted a peer-reviewed comprehensive search of multiple databases.

\section{Information sources and methods}

The databases searched in this project and their platforms were: MEDLINE All (Ovid), PsycINFO (Ovid), Embase (Ovid), Global Health (Ovid), Web of Science Core Collection (as licensed by Yale University, Core Collection included Science Citation Index Expanded (SCI-EXPANDED), Social Sciences Citation Index (SSCI), Arts \& Humanities Citation Index (A\&HCI), Conference Proceedings Citation Index- Science (CPCIS), Conference Proceedings Citation Index- Social Science \& Humanities (CPCI-SSH), Book Citation Index- Science (BKCI-S), Book Citation Index- Social Sciences \& Humanities (BKCI-SSH), Emerging Sources Citation Index (ESCI) --2015-present, Current Chemical Reactions (CCR-EXPANDED), and Index Chemicus (IC), Dissertations and Theses Global (ProQuest), Africa-Wide Information (Ebsco), CENTRAL (Cochrane Library), CINAHL (Ebsco), and Africa Index Medicus (Global Index Medicus). All titles/abstracts and texts were screened in Covidence except for the South African National ETD Portal (via netd.ac.za). This portal was searched online, but because records' export was not possible, the potentially relevant records were screened by an author (DV) online and only records requiring full text screening were added to Covidence. Each database was searched individually, using a combination of keywords and (if available) controlled vocabulary. No study registries were searched. No citation chaining was done.

Records published between 2006 and the dates of the searches in 2020 were retrieved. This date limit was used because this was the period of major policy shifts in WHOs infant feeding guidelines in the context of HIV. No limits were imposed with respect to study design and languages. Conference papers were not retrieved. Papers with animal subject indexing were excluded in some databases, but only if they did not also have human subject indexing. This search strategy was developed independently and did not use any published or validated filters. The MEDLINE search strategy was peer reviewed by an independent medical librarian using the Peer Review of Electronic Search Strategies Guideline [39].

\section{Search strategies}

The search strategies for each database are available in full. Search terms for Ovid Medline are presented in Table 1. While the strategies used appropriate syntax, indexes, and controlled vocabulary for the various databases, each one includes queries for the setting (South Africa) and queries for the broad topic (infant feeding). The strategies do not require an explicit reference to the WHO HIV infant feeding guidelines or The Code.

\section{Inclusion and exclusion study criteria}

For studies to be included, they needed to be peer reviewed, grey literature technical reports or theses and dissertations. We considered quantitative, mixedmethods and qualitative study designs. Studies had to be conducted in South Africa.

\section{Types of participants}

Eligible participants were women in South Africa who delivered a healthy live birth (birth to 24 months) with known infant feeding practices.

Table 1 Search terms for Ovid MEDLINE

1 [final searches]

2 exp Infant Nutritional Physiological Phenomena/

3 Milk, Human/

4 Infant Formula/ or milk substitutes/ or infant food/

5 (infant feeding* or breastfe* or breast-fe* or bottle fe* or bottlefe* or infant formula* or breastmilk or breast milk or wean or weaned or weaning).mp.

6 ((feeding or fed or food or foods) adj2 (solid or solids or formula or baby or babies or infant or infants or infancy)).mp.

7 or $/ 2-6$

8 South Africa/

9 south africa*.mp,jw.

10 (Port Elizabeth or Bloemfontein or Johannesburg or Durban or Polokwane or Mbombela or Klerksdorp or Kimberley or Cape Town).mp.

11 (Eastern Cape or Free State or Gauteng or KwaZulu-Natal or Limpopo or Mpumalanga or Northern Cape or Western Cape or North West province).mp.

12 or/8-11

$13 \quad 7$ and 12

14 limit 13 to $y r=$ "2006-2020"

1514 not (animals not humans).sh.

Ovid MEDLINE(R) ALL, searched on April 16, 2020, and updated on June 1,2020 


\section{Interventions}

We focused on two policy-level interventions, namely, the World Health Organization (WHO) Updates on HIV and Infant Feeding Guidelines (2016) [9], and The International Code of Marketing of Breastmilk Substitutes (The Code) [28, 29]. The updated 2016 (most recent) infant feeding guidelines recommend lifelong antiretroviral therapy for anyone diagnosed with HIV, including those who are pregnant and breastfeeding. It also provides guidance on appropriate infant feeding practices for mothers living with HIV [9]. Women who are HIV-positive and receiving antiretrovirals are advised to breastfeed following the same breastfeeding recommendations for HIVnegative women. The objective of The Code initially endorsed in 1981 by the World Health Assembly of WHO was to ensure safe and adequate nutrition for infants by protecting and promoting breastfeeding. It specifically sought to regulate the marketing of products such as breastmilk substitutes including formula, other types of milk, beverages and equipment (bottles, teats) $[28,29]$.

\section{Outcomes}

The infant feeding/breastfeeding outcomes considered were: Breastfeeding initiation within $1 \mathrm{~h}$ of birth; Exclusive breastfeeding up to 6 months; Any breastfeeding up to 12 months of age; and Continued breastfeeding from 12 to 23 months.

\section{Screening}

All references retrieved were first de-duplicated by $\mathrm{KN}$, then uploaded into Covidence [40]. Two independent reviewers (DV and MVC) initially screened a sample of 20 references (titles/abstracts) to ensure consistency and measure inter-rater literature screening reliability.

\section{Data collection and analyses Data extraction}

Data were independently extracted and entered on a standard Microsoft Excel spreadsheet form by two authors (DV and MVC). Studies which did not meet inclusion criteria and outcomes were excluded. Any disagreement was resolved in consultation with the senior author (RPE). Data extraction fields included author names, journal name and year of publication, study design, location of study, sample characteristics, number of participants, and outcomes. These outcomes included: Breastfeeding initiation within $1 \mathrm{~h}$ of birth; Exclusive breastfeeding up to 6 months; Any breastfeeding up to 12 months of age; and Continued breastfeeding from 12 to 23 months.

\section{Assessment of methodological quality of the included studies}

We did not evaluate the methodological quality and risk of bias of the included studies since this is not required for a scoping review [37, 38].

\section{Analyses and reporting}

Our findings are reported based on the PRISMA Extension and Joanna Briggs Institute guidelines for scoping reviews. We analyzed the data extracted from included studies based on the HIV status of participants and their infant feeding practices and outcomes wherever provided.

\section{Results}

A total of 5431 citations were retrieved from eleven databases. Duplicates were removed in EndNote and by Covidence. Records from all the databases except National EDT Portal underwent title-abstract screening in Covidence; records from National EDT Portal underwent title-abstract screening on the National EDT Portal website. 35 National EDT Portal Records were identified as deserving full text screening and were added to Covidence at that stage. 1588 unique records were processed in Covidence and 179 records met the criteria for fulltext screening. The final number of included records was 83 (Fig. 1 PRISMA flow diagram).

\section{Characteristics of included studies}

Of the 83 studies included, nine were qualitative, 11 RCTs, and 63 observational. All nine South Africa provinces were represented; the highest number of studies were conducted in Kwa-Zulu Natal (34) and the lowest number in Northern Cape (2). Other studies were in Western Cape (25), Gauteng (15), Eastern Cape (14), Limpopo (13), North West (7), Mpumalanga (6) and Free State (5). Studies were conducted primarily in rural (31) and urban (25) settings; other settings included semi-rural (3), semi-urban (6) and peri-urban (22).

While the articles were published between 2006 and 2020, we interpreted findings in the context of the time period when the study was conducted. The number of articles were about evenly divided between the two periods of major changes in WHOs breastfeeding guidelines for HIV-positive women; prior to 2011 ( $n=40$ articles) and from 2011 onward ( $n=43$ articles).

Infant feeding practices in South Africa (2006-2010)

The studies conducted during 2006-2010, i.e. before the release of the 2010 guidelines recommended HIVpositive women on ARVs to exclusively breastfeed for the first 6 months after birth (Table 2) revealed that HIV-positive women with 0-6 months infants mainly practiced formula and mixed feeding [41-44]. EBF rates in this age group ranged from 13 to $77 \%[44,45]$. 


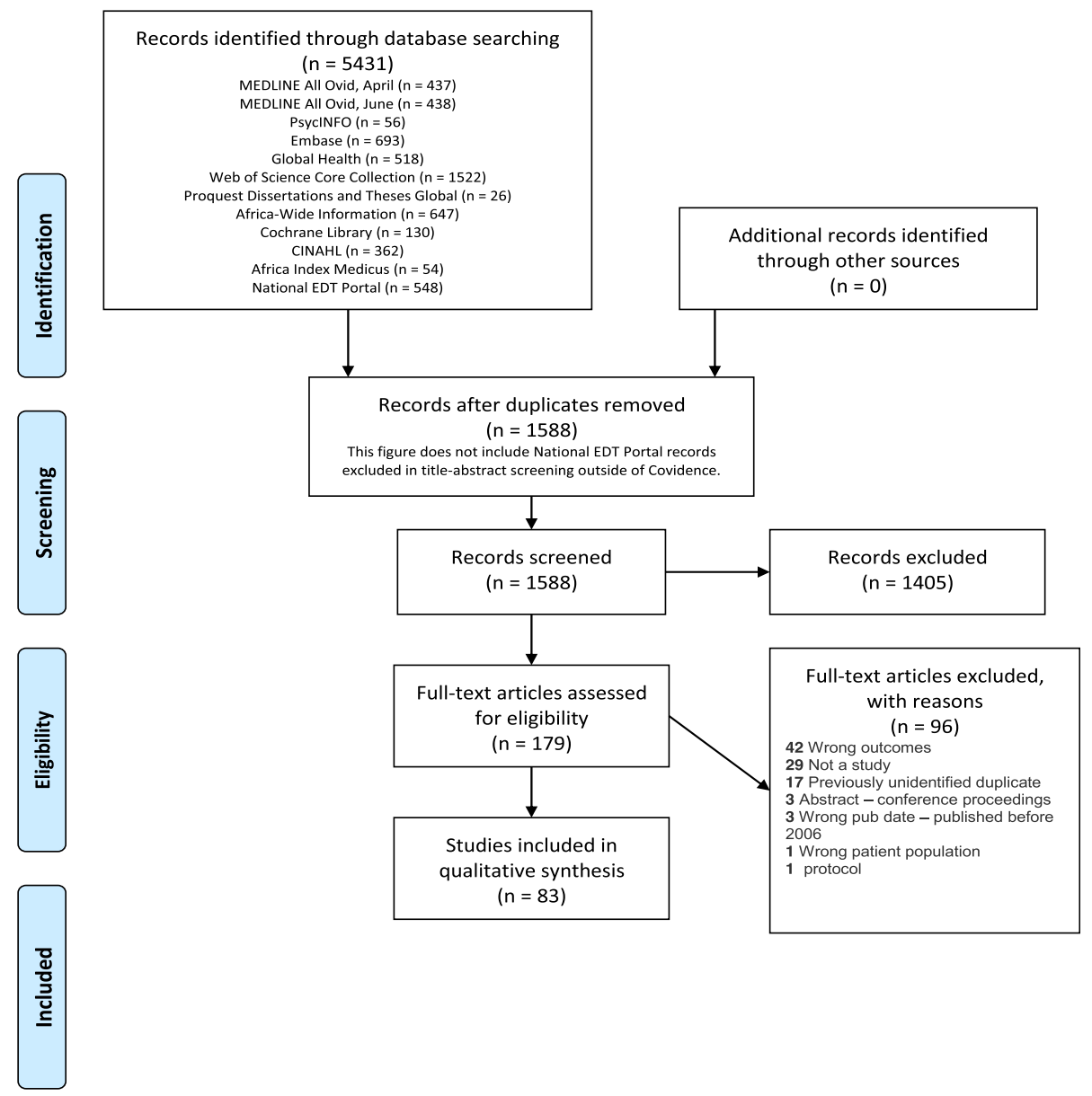

Fig. 1 PRISMA flow diagram)

During this period, it was common for HIV-positive women who initiated breastfeeding to stop doing so prior to 6 months after birth (1-3 months) [46-49]. Low rates of breastfeeding were observed for a variety of reasons including free formula distribution, not wanting to transmit the virus to the infant, and work/school obligations [43, 50-53]. However, for HIV-positive women who practiced exclusive formula feeding (EFF) initially, lack of access to infant formula was one of the reasons for mixed feeding [54, 55].

While breastfeeding initiation rates were high among HIV-negative women, ranging from 52.7 to $97 \%$ [48, 49, 56-59], EBF rates declined as liquids and solids were introduced before the infants were 6 months old [60-63]. Other reasons for infant formula use included nondisclosure of HIV status, family pressure, and cultural practices $[41,54,55,57]$.

\section{Infant feeding practices in South Africa (2011-2020)}

The post-2010 period (Table 3) after South Africa endorsed the 2010 WHO infant feeding guidelines for HIV-positive women recommending EBF for 6 months irrespective of HIV status resulted in a wide range of EBF rates among HIV-positive (26-99\%) and HIVnegative (12-92\%) women [64-69]. However, EBF duration was brief (1-3 months) [66, 70, 71]. While initiation of breastfeeding was high, there were low rates of EBF among HIV-negative women with introduction of liquids and other foods prior to 3 months [72-75]. In some instances, weaning occurred as early as 2 months [76]. HIV-positive women expressed fear of HIV transmission to their infants, as well as school and work commitments as reasons for discontinuation of EBF $[68,77-80]$.

\section{RCTs testing interventions to improve breastfeeding practices and outcomes}

Two major multi-country RCTs conducted during 2005-2008 among HIV-positive women and infants $\leq 6$ months old were the Kesho Bora trial $[81,82]$ and the PROMISE-EBF trial [83].

In the Kesho Bora trial [81, 82], conducted in Burkina Faso, Kenya and South Africa (Durban, Somkhele), HIVpositive pregnant women were randomized into two groups who received either triple ART during pregnancy 
Table 2 Included studies 2006-2010

\begin{tabular}{ll}
\hline Study & Participants \\
\hline Qualitative & \\
$\begin{array}{ll}\text { Doherty } & 40 \mathrm{HIV}+\text { women; mean age 24y; } \\
\text { et al., 2006 } & \text { community health workers. }\end{array}$
\end{tabular}

Doherty

et al., 2006

27 HIV+ women; mean age 25y.

Sibeko et al., 11 women (HIV+ and HIV-), mean age 2009 $25 y$

$\begin{array}{ll}\text { Andreson } & 14 \text { HIV+ women \& buddy pairs, > = 18y; } \\ \text { et al., } 2013 & \text { data for } 12 \text { women }\end{array}$

Randomized Controlled Trials

Bork et al., 751 infants (366 boys, 385 girls)

2014

ljumba et al., 1821 (intervention) and 2136 (control) 2015 pregnant women, median age 23y. 30 Com. Health workers (CHW): 15 Intervention and Control group respectively;

Bork et al., 1028 HIV+ mother-infant pairs 2013

Cournil et al., $795 \mathrm{HIV}+$ women 2013

Tylleskär et al., 2011

2579 mother-infant pairs

Doherty

et al., 2014

964 HIV- mother-infant pairs; mean age $24 y$ in Rietvlei and Umlazi and 25y in Paarl

Doherty et al., 2012

Sub-group analysis of data for 999 women who ever breastfed; median age $22 y$ in Rietvlei and Umlazi; 24y in Paarl.

Engebretsen et al., 2014

Ramokolo et al., 2015
2579 mother-infant pairs in 3 countries: 794 - Burkina Faso, 765 - Uganda, 1020 South Africa

641 HIV unexposed children, median age 22 months

\section{Infant feeding Outcomes}

25 women EBF, 15 EFF. 80\% (20) women who had chosen EBF introduced other liquids within the 1st month.
2 (18\%) who initiated breastfeeding were still EBF at 12 wks.; 3 stopped between 6 and 12 wks.; Formula-feeders: 88\% (14) did not give breast milk to their infants.

FF - 4 women; MF - 5; EBF - 2 women. $25 \%(1 / 4)$ women who chose to formula feed was able to EFF.

Study end date (2 to 6 months infants), -6 women were $\mathrm{EBF}$ and 6 were FF.

Ever breastfed: Durban $-57.1 \%$ (101), KwaZulu 80.9\% (72). Breastfeeding (4-6 months): $41,53 \%$ for Durban and KwaZuluNatal, respectively.

$76 \%(1242 / 1629)$ women in intervention and $74 \%(1380 / 1865)$ women in control initiated breastfeeding after birth; 34.4\% (561) intervention and 32.5\% (607) control breast-fed within $1 \mathrm{~h}$ of birth.

56\% (565) women were still breastfeeding at 3 months postpartum: $30 \%$ EBF, $18 \%$ predominant breastfeeding, and $8 \%$ partial. EBF: $90.4,73.1,69.9,56.8$, and $80.0 \%$ for Bobo-Dioulasso, Mombasa, Nairobi, Durban, and Somkhele, respectively.

$77.7 \% 618$ initiated breastfeeding at birth; 22.3\% (177) mothers never breastfed.

EBF prevalence in South Africa at 12 weeks (24-h recall) in the intervention and control groups: 10\% (56/535) 6\% (30/485), respectively.

34\% (114/330), 20\% (57/283) and 36\% (127/351) of HIV-negative women in Paarl, Rietvlei and Umlazi, respectively, stopped breastfeeding before 6 months postpartum

At 12 weeks postpartum - 20\% HIV- and $40 \%$ HIV+ women had stopped breastfeeding; 97\% HIV- women and 42\% HIV+ women ever breastfed.

$<4 \%$ women in Burkina Faso and about $50 \%$ in South Africa initiated breastfeeding within the 1st hour of birth.

Infants using any breast milk changed from 89.3\% (3 weeks) to $79.4 \%$ (12 weeks); Cereal use at 12 weeks $-79.5 \%$ who were not breastfed, and 59.6\% who were breastfed.

\section{Findings}

Women who chose to EFF had problems accessing formula milk; women were only able to maintain exclusive feeding practices for a short time due to a variety of constraints; Those who chose FF reported concern about HIV infection was the top reason for their infant-feeding choice.

HIV-positive women encounter many challenges in maintaining exclusive infant feeding, such as insufficient support from health staff and family pressure.

Non-disclosure of HIV status influenced feeding choices, which resulted in mixed feeding. Bad infant feeding advice created confusion and resulted in subpar practices such as mixed feeding.

Buddies can provide good support for $\mathrm{HIV}+$ women.

Not breastfeeding was associated with increased risk of serious infections particularly between 0 and 2.9 months.

CHWs had positive effect on EBF, particularly on HIV- women.

Overall, EBF was brief, particularly for boys.

By 6 months post-delivery, infants weaned/ not breastfed had approximately sevenfold higher risk of dying compared with infants being breastfed.

No differences found for the prevalence of diarrhea at age 12 weeks or 24 weeks between the clusters within the countries; No significant change in EBF rates for South Africa which were low at baseline.

For HIV-unexposed infants: low birthweight and short rates of breastfeeding increased risk of hospitalization/death during 1 st 6 months of birth.

Less than optimal early feeding practices; Early cessation of breastfeeding occurs among both HIV- and HIV+ women.

Behavior change may not have occurred in South Africa.

Infant feeding actions in the first 12 weeks can predict the development of childhood overweight and obesity. 
Table 2 Included studies 2006-2010 (Continued)

\begin{tabular}{lll}
\hline Study & Participants & Infant feeding Outcomes \\
\hline Observational & & \\
$\begin{array}{lll}\text { Goga et al., } & 665 \mathrm{HIV}+\& 218 \mathrm{HIV} \text { - women (age range } & \text { Complete breastfeeding cessation (CBC) } \\
2009 & 21-30) \text { and infants; } & \text { HIV+: 43.6\% (88) reported CBC by 24 } \\
& & \text { weeks.; HIV-neg: } 97 \% \text { initiated EBF. }\end{array}$
\end{tabular}

Becquet $\quad 2190 \mathrm{HIV}+$ women, aged $\geq 16$ years et al., 2009

Bland et al., 2491 women (1253 HIV+, 1238 HIV-); $2007 \quad$ median age 25

Bland et al., HIV-women (1219 infants); HIV+ women $2008 \quad$ (1217 infants);

Chetty et al., 2340 women (1197 HIV-, 1143 HIV+); $2014 \quad$ Median age: HIV- (21.8y); HIV+ (25.1y)

Coovadia et al., 2007

2722 HIV+ and HIV- pregnant women, median age, 25.1y

Doherty et al., 2007

$635 \mathrm{HIV}+$ mother-infant pairs, mean age: Intent to EFF, 25.8y; Intent to EBF, 25.3y

Ghuman et al., 2009

168 HIV+ \& HIV-women, mean age 24y

et 2009

Goga et al., $\quad 665$ HIV+ and 218 HIV- women; Median 2012 age: HIV-pos 25; HIV-neg 23

Matji et al., $\quad 222 \mathrm{HIV}+$ and $53 \mathrm{HIV}$ - women; 2009

Patil et al., 2053 infants; median age 3-12 days 2015
$90 \%$ of infants in both studies continued to be breastfed by 3 months of age; Mixed feed $-22 \%$ of infants by 3 months of age.

HIV+ women (EBF -78\%; replacement feeding 42\%; HIV- women: 75\% maintained intentions to EBF and $<1 \%$ (11) infants were not breastfed.

Median duration of EBF: HIV-, 177 days; $\mathrm{HIV+}, 175$ days; EBF at 3 \& 5 months: HIVwomen (83.1, 76.5\%); HIV+ women (72.5, $66.7 \%)$ respectively. HIV+ (175 days); Birth to 5 months feeding patterns: EBF - HIV- 76.9\% (920); HIV+ $66.7 \%$ (762); Mixed feeding HIV- 11.9\% (143); HIV+ 8.8\% (101); No $24.1 \%(275)$

83\% (1132/1372) HIV-exposed infants initiated EBF from birth; median time for $\mathrm{Cu}^{-}$ mulative EBF, 159 days. EBF at 26 weeks $37 \%$ (415/1132).

$13 \%$ who intended to breastfeed were EBF at 12 weeks; $42 \%$ mixed feeding; Predominantly breastfeeding (11\%); EFF (33.5\%).

97\% (163) infants got breast milk as their first feed, 3\% (5) were formula-fed; At 14 weeks: EBF was 18\%; $52 \%$ got water; and $73 \%$ solids; $87 \%$ (20/23); Week 14: $11 \%$ $\mathrm{HIV}$ + women were EBF, and 63\% (12/19) mixed feeding.

EBF at 3 weeks: HIV+ $42 \%$ (130) vs HIV17\% (33); 47\% (271) HIV+ women reported no breastfeeding; HIV- women at weeks 3 and 12: 17\% (33) and 3\% (5) practiced EBF.

At 6 weeks: 94\% HIV- mothers were breastfeeding, 69\% HIV+ mothers were FF; Intro of food by 6 weeks: $14 \%$ HIVmothers; 1 HIV+ mother had stopped breastfeeding by 6 weeks.

Breastfeeding initiation within $1 \mathrm{~h}-59.7 \%$; EBF at 30 days - 29.5\%; Partially Breastfed at 30 days $-36.6 \%$; Completely weaned by 30 days $-2.6 \%$.
Median duration of EBF: HIV- (179 days); breastfeeding - HIV-10.4\% (125); HIV+

\section{Findings}

Although national guidelines advise HIV+ women to breastfeed, they stop by 24 weeks; $39-44 \%$ of women practicing EBF/ PBF at week 3 complied with recommendations.

Breastfeeding duration is the primary contributor to HIV postnatal transmission; risk is quite similar for both exclusive \& predominantly fed infants; Risk of postnatal HIV infection was 3.9\% for infants breastfed less than 6 months, and $8.7 \%$ for those breastfed for at least 6 months.

For most women counselling helped with matching infant feeding intentions based on existing resources for appropriate feeding. Most HIV+ women did not have resources for safe replacement feeding, so they decided to EBF.

Both HIV+ and HIV- women can maintain EBF for 6 months with support in the home from trained lay counselors.

Breastfeeding did not increase postpartum weight loss; HIV+ women lost less weight during 1 st 6 months \& 12 months postpartum than HIV- women.

Mixed breastfeeding increased HIV transmission risk; EBF infants were less likely to get HIV than breastfed infants who used solid foods; HIV+ women can receive support to EBF.

Risk of getting HIV or death in both breastfeeding groups was high due to low rates of EBF; Inappropriate infant feeding choices were made based on the availability of 3 factors (piped water, electricity, gas or paraffin for cooking fuel, and early disclosure of HIV status).

Most women were not adhering to recommended infant feeding guidelines by 14 weeks of age; Women were unable to maintain EBF. HIV+ mothers breastfed at birth and more likely to formula feed than HIV- women.

While feeding practices were subpar among both groups of women, HIVpositive women engaged in more safer practices.

Influences in the home environment resulted in changes in infant feeding practices.

Shift from EBF in the first month of life. Liquids and solids were usually given to infants in the first month. 
Table 2 Included studies 2006-2010 (Continued)

\begin{tabular}{|c|c|c|}
\hline Study & Participants & Infant feeding Outcomes \\
\hline $\begin{array}{l}\text { Rollins et al., } \\
2013\end{array}$ & $\begin{array}{l}2789 \text { women; Median age: HIV-pos } \\
25.0 y \text {; HIV-neg } 21.7 y\end{array}$ & $\begin{array}{l}81.4 \% \text { HIV+ and } 92.9 \% \text { HIV- mothers EBF at } \\
6-8 \text { weeks; } 61.8 \text { and } 72.6 \% \text { at } 3-4 \text { months; } \\
\text { median time for cessation of } \\
\text { breastfeeding- } 171 \text { days. }\end{array}$ \\
\hline $\begin{array}{l}\text { Rossouw } \\
\text { et al., } 2016\end{array}$ & $\begin{array}{l}47 \text { mother-infant pairs, } 25 \mathrm{HIV} \text {-exposed } \\
\text { and } 22 \mathrm{HIV} \text {-unexposed infants }\end{array}$ & $\begin{array}{l}\text { HIV-exposed infants: One mother initiated } \\
\text { breastfeeding and continued up to } 18 \\
\text { months; HIV-unexposed infants: all mothers } \\
\text { initiated breastfeeding with }>50 \% \text { within } \\
\text { an hour of birth. } 62 \text { and } 52 \% \text { of HIV- } \\
\text { unexposed mothers were breastfeeding at } \\
12 \text { and } 18 \text { months respectively. No infant } \\
\text { EBF at } 6 \text { months. }\end{array}$ \\
\hline
\end{tabular}

Ahmadu-Ali 386 women, mean age 25y et al., 2013

Faber et al., 505 infants, mean age 9 months; 441 2007 mothers, 64 caregivers, mean age $25 y$

Kyei et al., 2660 women, 13-50 years 2014

Ladzani et al., 815 HIV-positive women; mean age $2011 \quad 27.7$ years

Ukpe et al., 33 mothers \& infants; Mean age women 2009 - 30.7y; Mean age infants - 3.5 months.

Yako and 60 women, mean age $26.5 y ; 53 \%$ (32) Nzama, 2013 were HIV-negative and 46.7\% (28) were HIV-positive

Zunza et al., 95 HIV-positive mother-infant pairs, $2011 \quad$ Mean age, 27y

Gbadamosi 186 infants, ages 1 to 12 months et al., 2017

Aku A., 2013125 HIV-positive mother-infant pairs, mean age, 27.8 years

Abusomwan, 395 HIV-pos mothers; 14 to 49 years Osaigbovo

Ebenezer,

2011

JacobsJokhan, D. 2011 200 HIV-pos women, mean age 30y
At 6 weeks: $53.1 \%$ (205) women were EBF; 26.6\% (103) EFF; $20.3 \%$ (78) mixed feeding. EBF at 6 weeks: $52.7 \%$ (157) - HIV-neg vs 60.6\% (43) HIV-pos.

Breastfeeding initiated - 96\% infants; breast milk only - 58\%; mixed feeds - 23\%; bottle feeds only $-18 \% .61 \%$ infants had solid foods before 6 months.

$42.5 \%$ vs $57.5 \%$ women were still breastfeeding; $70.6 \%$ of those who stopped breastfeeding breastfed $<24$ months.

50\% EFF, 35.6\% EBF, 12.4\% mixed feeding. EBF within $1 \mathrm{~h}$ of delivery $-<50 \%$; EFF within $1 \mathrm{~h}$ of delivery - > 50\%.

ERF - 50\% (15/30); EBF - 27\% (8/30); Mixed feeding 23\% (7/30).

At six weeks: EBF group - 13.3\% (8/19)

breastmilk only; mixed feeding $-11.7 \%$ (7/ 19). EFF group - formula only $30 \%(18 / 41)$; Mixed feeding - 15\% (9/41).

EFF - 97\% (62); Formula - 78\% (50); EBF - 2 women; Mixed feeding - 19\% (12).

$0.6 \%$ infants were EBF for > 3 months; 78\% breastfeeding at 9 months; $39.5 \%$ mixed feeding by end of 1 st month; $0.6 \%$ $\mathrm{EBF}>6$ months.

Replacement feeds $-84.3 \%$; Mixed feeding $-11.2 \%$; Intro of solids $-10.4 \%$; Mean age for intro of solids - 47 days.

EBF - 77.7\%, 6 weeks after delivery; Mixed feeding - 3\%; replacement feeding - $19.3 \%$.

\section{Findings}

EBF was associated with less adverse

events with mixed feeding or not breastfeeding in both HIV exposed and unexposed infants.

Among both groups, there was low compliance with breastfeeding guidelines and dietary diversity.

Breastfeeding rates were low in HIVexposed infants due to free formula distribution at health facilities.

HIV- women reported more counselling during antenatal care than HIV+ women; EBF was lower in HIV+ than HIV- women.

Exclusive breastfeeding to age 6 months was rarely practiced. Trained community health workers should help with poor infant feeding practices and micronutrient deficits.

Study showed duration of breastfeeding in Vhembe district decreased from $>24$ months to just 18 months.

Knowledge gaps of PMTCT and infant feeding policy contributed to inappropriate feeding choices. Variables associated with mixed feeding: Vaginal delivery; infant hospitalization, and currently pregnant. Variables associated with FF: older age, knowing the HIV status of the infant; and higher HIV transmission/breastfeeding knowledge.

ERF was the most frequent infant feeding practice. Women who FF used different types of commercial milk. Quality of counselling should be strengthened to enhance infant feeding practices.

Educate mothers on best infant feeding practices, including non-introduction of foods/liquids at inappropriate ages.

Advice needed on breast health during breastfeeding period and optimal infant feeding practices.

Complimentary foods provided at an early age; EBF was rarely practiced; Interventions needed to support and promote recommended infant feeding guidelines.

Infant feeding choices influenced by family; SES factors affected growth and nutrition of HIV-exposed infants.

EBF was the primary infant feeding choice and practice; Hardly any mixed feeding occurred in this group of HIV-positive women.

EFF - 84.5\%; EBF -14\%; Mixed feed - 1.5\%. Study showed that babies born to mothers who did not receive infant feeding counselling were twice as likely to be HIV positive; Infant feeding counselling is necessary component of antenatal care; HIV-pos women should be counselled 
Table 2 Included studies 2006-2010 (Continued)

\begin{tabular}{|c|c|c|c|}
\hline Study & Participants & Infant feeding Outcomes & Findings \\
\hline & & & soon after diagnosis and throughout care. \\
\hline $\begin{array}{l}\text { Masters, D., } \\
2006\end{array}$ & 42 HIV-pos women, < 19 to 49 years & $\begin{array}{l}\text { Exclusively formula milk and water - } 52 \% \\
\text { (22); Mixed feeds - } 48 \% \text { (40). }\end{array}$ & $\begin{array}{l}\text { Cultural norms influence infant feeding } \\
\text { practices, particularly introduction of solids/ } \\
\text { liquids. Women EFF wanted to prevent HIV } \\
\text { transmission. }\end{array}$ \\
\hline $\begin{array}{l}\text { Mushaphi } \\
\text { et al., } 2008\end{array}$ & $\begin{array}{l}185 \text { mother-infant pairs; mean age, } \\
25.83 y\end{array}$ & $\begin{array}{l}\text { EBF ( } 0-6 \text { months) }-7.6 \% \text { of women; } 97 \% \text { - } \\
\text { still breastfeeding; } 3 \% \text { had stopped; } 43,2 \% \\
\text { gave solid foods at three months, and } \\
15 \%<2 \text { months. }\end{array}$ & $\begin{array}{l}\text { Early introduction of other foods; Although } \\
\text { breastfeeding was practiced by many of } \\
\text { the mothers, EBF was rare. }\end{array}$ \\
\hline $\begin{array}{l}\text { Some et al., } \\
2017\end{array}$ & $\begin{array}{l}1225 \text { mother-infant pairs- all sites; } 222 \\
\text { from East London, South Africa; > } 18 \\
\text { years }\end{array}$ & $\begin{array}{l}\text { EBF- first } 3 \text { days - } 93.4 \% \text { (199); Mixed } \\
\text { feeding first } 3 \text { days - } 2.3 \%(5) \text {. Breastfeeding } \\
\text { initiation within } 1 \mathrm{~h} \text { of birth }-57.7 \% \text {. } \\
\text { Median duration of any breastfeeding was } \\
40.6 \text { weeks. }\end{array}$ & $\begin{array}{l}\text { More mothers in South Africa had to } \\
\text { return to work after a few months, } \\
\text { stopping them from continuing to } \\
\text { breastfeed; Improvements needed in } \\
\text { breastfeeding and complementary feeding } \\
\text { of children, particularly those who are HIV- } \\
\text { exposed. }\end{array}$ \\
\hline
\end{tabular}

Legend: EBF Exclusive breastfeeding, EFF Exclusive formula feeding, MF Mixed feeding

through the breastfeeding period (intervention), or short course prophylactic therapy until delivery (control). All HIV-exposed infants received single-dose nevirapine at birth. Women were also counselled to either breastfeed with cessation by 6 months or formula feed from birth (free infant formula was provided for 6 months). The main objectives were to determine rates of HIV transmission, infant survival at 6 weeks and 12 months and adverse events. Bork and colleagues [81], found breastfeeding initiation to be lower in Durban (57.1\%) than rural Somkhele $(80.9 \%)$ among 751 HIV-exposed infants. Overall, they found that non-breastfed infants (0-6 months) had higher morbidity risks than those breastfed, with increased risk for serious infections (e.g. severe diarrhea) between 0 and 2.9 months [81].

The PROMISE-EBF trial was a behavior change intervention to promote EBF using peer counsellors in Burkina Faso, South Africa (Paarl, Rietvlei and Umlazi), and Uganda [47, 83-86]. This counselling intervention ( $N=2579$ mother-infant pairs) included one antenatal breastfeeding peer counselling visit and four postnatal peer visits. The two main outcomes of interest were prevalence of EBF and diarrhea at ages 12 and 24 weeks. Overall, Tylleskar and colleagues [83] found that EBF prevalence (all countries) in the intervention groups at 12 weeks was double that of the control groups. However, South Africa had exceedingly low EBF rates at baseline (10\%), compared with $79 \%$ in Burkina Faso and $82 \%$ in Uganda [83]. There were no significant differences in the prevalence of diarrhea (all countries) between the two groups at either 12 or 24 weeks of age [83]. Finally, the authors [83] found that while the peer counselling intervention was effective in increasing EBF rates in Uganda and Burkina Faso, it was not effective in improving breastfeeding rates in South Africa.

\section{Violations of the international code of marketing of breastmilk substitutes}

South Africa took another bold step in 2012 to enforce The Code via legislative action (i.e., regulation R991 of 2012), which sought to regulate the sales, advertising, marketing, information and education of foods promoted for infants and young children [87, 88]. The specific objective of regulation R991 was to protect and support breastfeeding by creating an environment free from the relentless marketing strategies of BMS manufacturers, and prevent conflicts of interest among the healthcare staff or other child care providers [87, 88]. Unfortunately, this legislation has had limited positive effects as violations of the Code are still prevalent, highlighted in the three articles discussed below.

Of the three included studies which focused on Code violations, two were Master of Public Health theses [89, 90] and the other was an expert commentary from academics [33] (Table 3). Muravha [89] investigated Code violations among health workers in four Provinces and 40 health facilities and found that four health workers accepted free gifts (pens, calendars, posters) from a BMS company, despite being aware of the R991 regulations. Health workers also received education materials (leaflets, booklets) and equipment (South African water bags for adult usage) which were branded with the manufacturer's name, but not the name of a specific product marketed by the BMS company. Radebe [90] examined media (radio, television, print) infractions and identified 30 marketing violations from 117 baby products (formula, bottles and teats) advertised in magazines targeting primarily pregnant women or families. The author reported that these numbers are likely to be underestimated, since the analysis did not include all media sources. 
Table 3 Included studies 2011-2020

\begin{tabular}{|c|c|c|c|}
\hline Study & Participants & Infant feeding Outcomes & Findings \\
\hline \multicolumn{4}{|l|}{ Qualitative } \\
\hline $\begin{array}{l}\text { Horwood } \\
\text { et al., } 2019\end{array}$ & 11 HIV+ women, 15-41y & $\begin{array}{l}\text { EBF for } 6 \text { months }-3 \text { women; } 4 \text { stopped } \\
\text { breastfeeding, and } 2 \text { were MF by } 6 \text { months }\end{array}$ & Health workers influenced feeding decisions \\
\hline $\begin{array}{l}\text { Chaponda } \\
\text { et al., } 2017\end{array}$ & $30 \mathrm{HIV}+$ women, $>18 \mathrm{y}$ & $\begin{array}{l}\text { EBF - } 50 \% \text { mothers; Initiation of } \\
\text { complementary foods from } 1 \text { to } 4 \text { months }\end{array}$ & $\begin{array}{l}\text { Nurses primarily influenced feeding choices, } \\
\text { followed by mothers and other relatives }\end{array}$ \\
\hline $\begin{array}{l}\text { Jama, } \\
\text { Ngcwalisa } \\
\text { et al., } 2017\end{array}$ & $\begin{array}{l}22 \text { women (mixed HIV status); median } \\
\text { age } 25.5 \mathrm{y} \text {. }\end{array}$ & $\begin{array}{l}\text { EBF for the } 1 \text { st } 6 \text { months - 23\% (5/22); } \\
\text { Food/fluids before } 6 \text { months - 77\% (17/22) }\end{array}$ & $\begin{array}{l}\text { Health workers were a strong influence on } \\
\text { choice; All women experienced challenges } \\
\text { including incorrect info from health staff, } \\
\text { family pressure and having to return to } \\
\text { school/work. }\end{array}$ \\
\hline $\begin{array}{l}\text { Mushaphi } \\
\text { et al., } 2017\end{array}$ & 37 caregivers, $\geq 16 y ;$ & $\begin{array}{l}\text { Over } 90 \% \text { initiated breastfeeding after } \\
\text { delivery; EBF by } 3 \text { months - < } 1 \% \\
\text { No infant was EBF for up to } 6 \text { months; } \\
\text { Liquids/solids by the } 2 \text { nd month- } 100 \%\end{array}$ & $\begin{array}{l}\text { EBF up to } 6 \text { months was not practiced; most } \\
\text { women believed that breast milk alone was } \\
\text { inadequate for baby's needs and introduced } \\
\text { water and other foods before } 6 \text { months. }\end{array}$ \\
\hline $\begin{array}{l}\text { Ntuli and } \\
\text { Modibedi, } 201\end{array}$ & 32 HIV-positive women, 22-38 years & $\begin{array}{l}\text { EBF - 68.8\% women; EFF - 31.3\%; MF - } 5 \\
\text { mothers }\end{array}$ & $\begin{array}{l}\text { Healthcare staff, SES, past participation in } \\
\text { PMTCT and fear of infecting the baby, } \\
\text { impacted mothers on infant feeding } \\
\text { choices; Counselling needed throughout } \\
\text { the perinatal period to enable mothers to } \\
\text { choose and maintain appropriate infant } \\
\text { feeding choice }\end{array}$ \\
\hline
\end{tabular}

\section{Randomized Controlled Trials}

Jones et al., $1368 \mathrm{HIV}+$ pregnant women and 2018 male partners; Women's mean age $28 y$

Reimers et al., $619 \mathrm{HIV}+$ mothers (277 control and 2018273 intervention); Median age (years): control 28.8y (27.5-30.0); intervention 28.4y (27.5-29.2)

\section{Observational}

West et al. 2019

Quant - 8116 HIV+ and HIV- women; Qual- 12 healthcare providers, 22 $\mathrm{HIV}+$ women, median age $31 \mathrm{y}$.

Goosen et al., Cross-sectional - 140 women, mean 2014 age $26.4 y$; Focus groups - 65

Chakona,G., $\quad$ Survey and FGD; 84 caregiver-infant 2020 pairs (0-24 m); mean age 34.7y

Zulliger et al., 207 pregnant and 203 post-partum 2013 women; mean age pregnant women 28.6y and 30.0y postpartum

Budree et al., 1071 women, median age 25.8y; 2017

Ellis, K., $2013 \quad 260 \mathrm{HIV}+$ and $251 \mathrm{HIV}$ - women
Overall EBF - 74\% women; EFF - 13\%; Infant feeding at 6 weeks: EBF - 73.7\%; EFF $12.6 \%$.

EBF rates at 22 weeks: 44.68\% (105/235) control and 42.75\% (109/255 intervention group.

Initiated breastfeeding - 86.3\%. 93.1\% HIV+ women initiated breastfeeding vs $66.3 \%$ HIV- women. EBF: $86.3 \%$ (day 7), 73.1\% (week 14) and $51.7 \%$ (month six).

Initiated breastfeeding -77\% women; EBF 6 94\% suboptimal breastfeeding: 36\% predominant breastfeeding, 27\%; partial breastfeeding, 31\% not breastfeeding; 44\% introduced food/formula milk to infant; Intro of foods $-75 \%<3$ months old.

1st 6 months: EBF 36\%; FF - 49\%

Ever breastfed - 22\% (45) women; Ever used formula - 93\% (188); Mean time cessation 10 weeks.

Initiation of BF at birth - 86\%; EBF for 6 months - 13\%; Solid foods before 4 months - 19\%; 46\% HIV-exposed infants vs $96 \%$ unexposed were breastfed at birth. Women who initiated breastfeeding -26\% HIV-pos vs $12 \%$ HIV-neg women did EBF for $\geq 6$ months.

By 3 months: EBF -30.9\% HIV-pos; MF 86.2\% HIV-neg women.
Study intervention was not effective on EBF. Male involvement, HIV disclosure, or stigma did not influence EBF

EBF rates at the final interview (about 22 weeks postpartum) were similar for the control and intervention groups.

Overall exclusive breastfeeding and breastfeeding intent was higher among HIVneg than HIV-pos women. Infant feeding choices were guided by a variety of reasons including healthcare staff, finances and social pressure

Women engaged in suboptimal infant feeding methods; EBF was hardly done and other liquids and foods introduced at an early age

Although women knew the benefits of breastfeeding, it was hardly practiced due to cultural and other reasons; Most infants were weaned by 2 months

Advice from healthcare staff was a strong indicator of breastfeeding; Women with running water in home more likely to breastfeed

Poor dietary practices and use of nonnutritious foods were noted; EBF decreased after 3 months, early use of other foods, and low use of iron rich foods between 6 and 9 months.

Although early infant feeding practices were low among HIV+ and HIV- women, HIV+ women continued safe 
Table 3 Included studies 2011-2020 (Continued)

\begin{tabular}{|c|c|c|c|}
\hline Study & Participants & Infant feeding Outcomes & Findings \\
\hline & & & infant feeding practices for 3 months. \\
\hline $\begin{array}{l}\text { LeRoux et al., } \\
2020\end{array}$ & $\begin{array}{l}869 \text { mother-infant pairs; Age: HIV+ } \\
28 y, \text { HIV- } 27 y\end{array}$ & $\begin{array}{l}\text { Early initiation of breastfeeding: All - 90\%; } \\
\text { HIV-pos 87\%; HIV-neg 94\%; Duration of EBF } \\
\text { (months): All 1.4, HIV-pos 1.5; HIV-neg 1.4. }\end{array}$ & $\begin{array}{l}\text { Suboptimal breastfeeding practices } \\
\text { increased risk of infections for infants. }\end{array}$ \\
\hline $\begin{array}{l}\text { LeRoux et al., } \\
2018\end{array}$ & $\begin{array}{l}521 \text { mother-infant pairs, Median age: } \\
\text { All } 28 y \text {, HIV-pos women 29y, HIV-neg } \\
28 y\end{array}$ & $\begin{array}{l}\text { Median duration of breastfeeding - } 6 \\
\text { months in HIV-exposed vs } 10 \text { months for } \\
\text { HIV unexposed infants }\end{array}$ & $\begin{array}{l}\text { HIV exposed infants might be at increased } \\
\text { risk of cognitive and motor delays, despite } \\
\text { being breastfed and mother receiving ART. }\end{array}$ \\
\hline $\begin{array}{l}\text { Zunza et al., } \\
2018\end{array}$ & $\begin{array}{l}316 \text { mothers-infants: } 188 \text { HIV+ } \\
\text { mothers and } 128 \text { HIV- mothers; HIV- } \\
\text { pos b/feed } 27.99 y \text {; HIV-neg formula }\end{array}$ & $\begin{array}{l}\text { All HIV-neg mothers breastfed; HIV-pos (2 } \\
\text { weeks): Breastmilk 42\%; Formula 58\%. }\end{array}$ & $\begin{array}{l}\text { Analysis indicates inadequate duration of } \\
\text { breastfeeding among HIV-pos and HIV-neg } \\
\text { mothers. }\end{array}$ \\
\hline
\end{tabular}

Kennedy, Y 132 mothers, 18-42y, with mean age et al., $2016 \quad 27 y$

Nguyen, K., 471 mother-infant pairs; Median age 2017

Van De

Venter, C., 2019

Tchakoute et al., 2018 unexposed uninfected infants 28 years

584 women; median age 28 years
749 HIV-exposed uninfected and HIV-

At 6 weeks: EBF - 69.36\%; FF - 15.21\%; MF15.21\%; Complimentary foods by 6 weeks $15.32 \%$.

Ever EBF - 91\%; Median duration of EBF1.5 months; EBF $\geq 4$ months - $24 \%$.

Infant feeding intentions:

EBF - 81\%; EFF- 16\%; MF - 3\%. 1 week postpartum: EBF -9\%; EFF, 2\%; MF $90 \%$.

EBF at birth - 99\% HIV-exposed infants vs. 92\% HIV-unexposed infants.
Horwood et al., 2018

Jackson et al., 2019

du Plessis

et al., 2016

Faber et al., 2016

Fuls et al., 2020

200 infants 6-12 months, mean age 8.54 months

Madiba et al., 202 post-natal women, mean age 2015 was 31.4y.
4172 caregivers (mothers, fathers and other relatives); Age $>15 y$
Mothers: EBF - 49.8\% MF- 23.1\%; No BF 27.0\%; Other caregivers: EBF -11.8\%; MF$23.4 \%$ and no breast milk - $62.3 \%$.

National EBF rates (4-8 weeks of age) were: $22.9 \%$ in $2010 ; 35.7 \%$

in $2011-12$ and $59.1 \%$ in 2012-13.

Breastfeeding initiation - 75.2\%; Infants $<6$ months: EBF - 38.5\%; EFF - 19.7\%; BF at 1215 months old: $32.5 \%$

Ever breastfed: rural - 79.1\%; urban - 78.5\%; BF 18-24 months - 14.4\%.

Overall BF - 87\%,

Complementary feeding (6-8 months)- $82 \%$ Mean BF - 7.5 months; BF > 6 months $53.7 \%$

55.6\% EBF and EFF mothers practiced MF. EFF - 56.8\%.

$\mathrm{EBF}(\leq 6$ months age) $-5.9 \%$; EBF (6 months) $-70.1 \%$. Intro of liquids and semi-
Although women had high knowledge on benefits of breastfeeding, they made unsuitable choices

Sub-optimal levels of EBF identified; Need for breastfeeding support

Majority of women engaged in mixed feeding; non-disclosure of HIV status impacted infant feeding practices

Infants EBF had lower cumulative infectious disease incidence than those who were not breastfed; no significant difference in mortality among HIV-exposed infants and HIV-unexposed infants during the first year of life in this cohort; EBF for just 4 months had protective effects on morbidity up to 1 year.

Although breastfeeding practices in the study were higher than previous studies, problems persist. Breastfeeding support needed for HIV+ women and those returning to work/school.

There was an increase in early EBF among infants 4 to 8 weeks due to major national policy change in breastfeeding from 2010 to 2013. Lower odds of EBF for mothers: with high SES; HIV- positive, unplanned pregnancy, primipara, caesarean delivery, and no breastfeeding counselling.

Results indicated subpar infant feeding practices with both under and over nutrition observed.

Dietary diversity (minimum) attained by < $25 \%$ children; High levels of animal protein \& cholesterol vs low levels of fiber \& plant protein for urban vs rural children (18-24 months)

6.5\% children experienced feeding problems, such as oral motor dysfunction; Care giver education and health-care professional training needed on transitional feeding.

EBF and EFF mothers had problems adhering to initial infant feeding choice. Interventions needed to address cultural practices and other factors impacting EBF among HIV-pos women

Interventions to encourage appropriate infant feeding practices, needed to prevent 
Table 3 Included studies 2011-2020 (Continued)

\begin{tabular}{|c|c|c|}
\hline Study & Participants & Infant feeding Outcomes \\
\hline & & $\begin{array}{l}\text { solids was } 2.5 \text { months and } 3.8 \text { months, } \\
\text { respectively. }\end{array}$ \\
\hline $\begin{array}{l}\text { Motadi et al., } \\
2019\end{array}$ & $\begin{array}{l}360 \text { participants; mean age adults - } \\
29.3 y \text {; mean age infants - infants were } \\
12.2 \text { months. }\end{array}$ & $\begin{array}{l}\text { Initiation of BF within } 1 \mathrm{~h} \text { of birth }-67.2 \% \text {. } \\
\text { Of the } 17 \% \text { of women who stopped BF: } 16 \\
\text { and } 14 \text { stopped within } 1 \text { month and } 3 \\
\text { months of delivery respectively. }\end{array}$ \\
\hline $\begin{array}{l}\text { Nieuwoudt } \\
\text { et al., } 2018\end{array}$ & $\begin{array}{l}298 \text { HIV-pos and HIV-neg women. } \\
\text { Median age } 29 y\end{array}$ & $\begin{array}{l}\text { Breastfeeding initiation - 99.5\%. HIV-pos } \\
\text { women (infants }<3 \text { months): EBF - } 44 \% \text {; FF } \\
-28.9 \% \text {. HIV-pos women (infants 3-6 } \\
\text { months): EBF - 31.8\%. }\end{array}$ \\
\hline $\begin{array}{l}\text { Pillay et al., } \\
2018\end{array}$ & $\begin{array}{l}73 \text { teenage mothers, } \leq 19(15-19) \\
\text { years }\end{array}$ & $\begin{array}{l}\text { Initiation of BF - 100\%. BF (Visit 1) - 68.5\%. } \\
\text { 14-week visit: EBF - 50.7\%; MF/No breastmilk } \\
\text { - 49.3\%. }\end{array}$ \\
\hline $\begin{array}{l}\text { Remmert } \\
\text { et al., } 2020\end{array}$ & 156 HIV-pos women, mean age 28.1y & $\begin{array}{l}\text { No initiation of BF: > 50\%. EBF- 28.2\%; EFF- } \\
71.4 \% \text {. }\end{array}$ \\
\hline $\begin{array}{l}\text { Seonandan \& } \\
\text { McKerrow, } \\
2016\end{array}$ & $\begin{array}{l}11 \text { dieticians, } 14 \text { nurses \& } 94 \\
\text { caregivers ( } 41 \text { infants }<6 \text { months; } 26 \\
\text { infants } 6 \text { to } 24 \text { months, and } 27 \\
\text { children } 2 \text { to } 5 \text { years) }\end{array}$ & $\begin{array}{l}\text { Ever EBF - } 76 \% \text {. } \\
\text { EBF (> } 3 \text { months) - 36\%; EBF (< } 6 \text { months) } \\
-84 \%\end{array}$ \\
\hline $\begin{array}{l}\text { Siziba et al., } \\
2015\end{array}$ & $\begin{array}{l}580 \text { mothers/caregivers; Mean age of } \\
\text { infants, } 2.9 \text { months. }\end{array}$ & $\begin{array}{l}\text { Initiated BF within 1st hour - } 90 \% \text {. EBF for } \\
\text { (infants } \leq 6 \text { months) - } 12 \% \text {; No BF }(\leq 1 \\
\text { month) - } 40 \% \text {; Mean duration of EBF }-2 \\
\text { months. }\end{array}$ \\
\hline $\begin{array}{l}\text { VanDerMerwe } \\
\text { et al., } 2015\end{array}$ & $\begin{array}{l}435 \text { mother-infant pairs; } \\
\text { Mean age } 26 y \text {; Infants } 1 \text { day - } 5 \\
\text { months }\end{array}$ & $\begin{array}{l}\text { Emalahleni vs Mbombela health subdistricts. } \\
\text { Early initiation of breastfeeding } \\
57 \% \text { vs. } 43 \% \text {; EBF } 60 \% \text { vs } 48 \% \text {; ERF - } 18 \% \text { vs. } \\
33 \% \text {. MF - } 19 \% \text { vs. } 15 \% \text {; Mean age for } \\
\text { complementary foods - } 50 \text { vs } 35 \text { days. }\end{array}$ \\
\hline
\end{tabular}
49 years

Makwela, M., 146 mothers

2019

Initiated breastfeeding - 94\%; EBF - 39\%; MF - 61\%; 5\% stopped breastfeeding $<1$ month after initiation.

\section{Findings}

stunting.

While the women were quite

knowledgeable about breastfeeding, this did not translate into appropriate practices.

HIV-positive mothers engaged in longer EBF and FF than the HIV-neg women. Mixed feeding occurred frequently

Early cessation of breastfeeding linked to maternal age $\leq 17 y$; Interventions needed to promote and support EBF

Low rates of EBF; Social support and services needed to promote EBF. Primary reason for not breastfeeding was fear of HIV transmission to the child.

Although there have been better breastfeeding rates since 2003, EBF occurs for a short time. Appropriate feeding of infants and young children varies at state hospitals. Regular training needed for staff.

Interventions needed to address knowledge and increase EBF, particularly at the community levels. Work, school, health status and inadequate milk affected infant feeding practices.

Baby-Friendly Hospital Initiative (BFHI) in community contributed to better infant feeding practices

Issues that impacted EBF were work, school, family pressure, and knowledge deficits. Recommendation to increase individual counselling sessions.

While there are high rates of breastfeeding initiation, problems exist with the practice of EBF

Mandiwana, T., 160 mothers, 15-40 years 2017

EBF for 6 months - 6.25\%; EBF (4-6 months) $1.5 \%$.

Adherence to 6 months of EBF was inadequate. Complimentary foods introduced at an early age; Reasons for non EBF: not enough milk, crying baby, school or work.

Mohlajoa, K., 75 HIV-positive women, 18 to $45 y$ 2016

Initiation of BF (immediately after birth) $-67.6 \%$. EBF for 6 months - 40\%.

\begin{tabular}{|c|c|}
\hline $\begin{array}{l}\text { Morgan and } \\
\text { Jeggels, } 2015\end{array}$ & $\begin{array}{l}100 \text { HIV-positive mothers, mean age } \\
29 \text { years }\end{array}$ \\
\hline $\begin{array}{l}\text { Muravha, N., } \\
2014\end{array}$ & 122 health staff at 40 health facili \\
\hline $\begin{array}{l}\text { Radebe, P., } \\
2014\end{array}$ & $\begin{array}{l}4 \text { TV channels, } 9 \text { radio stations, } 116 \\
\text { magazines and } 10 \text { newspapers }\end{array}$ \\
\hline
\end{tabular}

4 violations by 4 health workers in 7.5\% (3/ 40) facilities (violation of Article 7.3) - receipt of free gifts.

30 violations from 117 baby product advertisements published in 8 of 169 magazines; No violations were found from advertisements on $\mathrm{TV}$, radio or newspapers
Interventions needed to educate women on infant feeding; Lack of support, fear of stigma and cultural norms contributed to poor EBF

Poor EBF practices; Women not aware of Government's policy to eliminate free formula; Consistent messaging needed on infant feeding

All health workers were familiar with the International Code of Marketing of Breastmilk Substitutes. Ongoing training needed on The Code

Code violations identified in (4.7\%) of magazines targeting mainly pregnant women. Data needed to determine full extent of violations in the media 
Table 3 Included studies 2011-2020 (Continued)

\begin{tabular}{|c|c|c|c|}
\hline Study & Participants & Infant feeding Outcomes & Findings \\
\hline Siziba, L., 2014 & $\begin{array}{l}580 \text { mothers/caregivers with infants } \\
<6 \text { months }\end{array}$ & $\begin{array}{l}\text { Initiation of BF within } 1 \text { h of birth }-90 \% \text {. } \\
\text { EBF - 12\%; No BF - } 16 \%\end{array}$ & $\begin{array}{l}\text { Low rates of EBF, and early intro to other } \\
\text { foods major concerns }\end{array}$ \\
\hline \multicolumn{4}{|l|}{ Other } \\
\hline Author & Type of document & Issue & Findings \\
\hline $\begin{array}{l}\text { Lake et al., } \\
2019\end{array}$ & Expert Commentary & Breastfeeding in SA and the BMS Industry & $\begin{array}{l}\text { Effective leadership urgently required to } \\
\text { stem violations of BMS industry }\end{array}$ \\
\hline
\end{tabular}

Legend: EBF Exclusive breastfeeding, EFF Exclusive formula feeding, MF Mixed feeding

Finally, Lake and colleagues' commentary [33] documented anecdotally the marketing strategies of the BMS industry and their reach to health workers and other stakeholders through sponsorships of conferences and other scientific meetings, misleading information on infant formula on company websites, health promotion materials and support for staff salaries. The authors called for improved leadership efforts in enforcing the Code and strengthening breastfeeding interventions.

\section{Discussion}

During the early years of the HIV pandemic, recommendations for infant feeding were guided by scientific evidence indicating that when safe feeding with breast milk substitutes was universally available, as was the case in the United States and other high income countries, it was appropriate to recommend for HIVpositive mothers to not breastfeed at all [21].

By contrast, as part of their infant feeding decisions HIV-positive mothers in low income countries needed to consider the risk of their children dying if they were not breastfed as a result of having access to safe replacement feeding alternatives. Since then, HIV infant feeding guidelines have evolved over time. WHO guidelines in this area switched from exclusive breastfeeding with abrupt weaning from the breast before 6 months to current guidelines recommending EBF for 6 months followed by breastfeeding continuation for at least 12 months if the mothers have ART access [9, 22-24].

The initial guidelines implemented in South Africa in 2008 [36] provided HIV-positive mothers with widespread access to cost-free infant formula at public health facilities. Unfortunately, these polices, albeit wellintentioned may have inadvertently negatively impacted the EBF behaviors among HIV-negative mothers and led to subsequent increases in infant morbidity and mortality in South Africa and similar settings [91]. Our review indeed suggests as reported in other studies that there may have been a spill-over from an infant feeding policy driven by HIV-positive women to HIV-negative mothers explaining why EBF rates are still low in South Africa $[44,92]$. Unfortunately, there is no evidence that EBF rates significantly increased after the Tshwane declaration.
One of the challenges highlighted in this review is that HIV usually coexists with poverty creating a syndemic-like effect in the lives of women, as breastfeeding was disincentivized in the early WHO guidelines, generating inequities in access to infant feeding choices. In addition, as the South African HIV infant feeding guidelines evolved and pushed for phasing out free formula distribution [25, 36], some key challenges remain: (i) changing breastfeeding behaviors, social norms and medical practices have been slower than desired; and (ii) marketing of BMS and Code violations have persisted. These factors have disproportionately affected HIV-positive mothers mainly located in rural and peri-urban areas of South Africa where not breastfeeding was associated with increased risk for serious infections (chronic diarrhea, lower respiratory tract infections) and death [45, 81, 84]. Further research is needed to address how poverty affects women's ability to successfully implement the national infant feeding guidelines for HIV-positive and HIV-negative women.

One of the strengths of this review is that it highlights diverse studies conducted in South Africa on breastfeeding in the era of HIV among both HIV-infected and uninfected women, and that EBF rates are subpar in both groups as a result of the premature introduction of liquids and solids. However, there is a dearth of policy-responsive implementation research to inform how the more recent HIV infant feeding national guidelines can be successfully implemented in South Africa, a country where this should be possible because there is now almost universal access to ART among HIV-positive women [93-96], and a call for strong protection, promotion and support for breastfeeding including those who are HIV-positive [33, 97]. As it has been found in other countries [98-101], our findings suggest that strong Code enforcement combined with increased investments in breastfeeding protection, promotion and support programs in South Africa are needed for the country to make progress towards meeting the United Nations target to increase breastfeeding rates to at least $50 \%$ by 2025 [17].

Because the infant formula distribution program was coordinated by the health sector, the findings from our review are highly consistent with previous studies showing that health workers play an important and influential role in counseling or advising mothers on infant feeding practices [77, 102-106]. 
Therefore, it is key that the WHO Code is properly enforced to allow for the environment conditions surrounding mothers in South Africa to become stronger enablers of optimal breastfeeding practices [106]. Unfortunately, in our review we did not find evidence that this has already started to happen yet in South Africa.

Although penalties exist for first and subsequent violations of regulation R991, with the first penalty being a fine and at most 6 months imprisonment [107], to date no individual or organization has been prosecuted for Code violations, a strong indicator of lack of enforcement or commitment to change the status quo. Thus, routine monitoring of this key legislation is required as encouraged by other academics and advocates [33, 97, 108]. As such, enforcing regulation R991, particularly the outreach to health workers by BMS manufacturers and their associates is imperative.

\section{Conclusion}

The free distribution of infant formula combined with the BMS industry's marketing practices that violate the WHO Code have played a role in suboptimal breastfeeding practices among both HIV-positive and negative women in South Africa [33, 109, 110].

This scoping review integrated evidence on infant feeding practices, especially EBF rates among HIV-positive and HIV-negative women in South Africa in the context of rapidly evolving HIV infant feeding guidelines from the WHO. Although highly effective ARTs has made breastfeeding for HIV-positive women safe, and South Africa has widespread access to ART [93, 95, 96], it is discouraging that women continue to cite fear of HIV transmission to their infants as a reason for either not breastfeeding or doing so for short periods of time. This finding calls for improved access to high quality breastfeeding counselling, education and awareness campaigns from the local health care facility to the national level.

Although monitoring and enforcement of the Code remain nonexistent, there has been progress in strengthening legislation. The most recent Status Report (2020) from WHO, UNICEF and IBFAN found 70\% $(136 / 194)$ of WHO Member States had new Code legislation [111]. However, only 31 countries regulated milk products for infants up to at least 36 months. Moreover, just 58\% (79/136) ban the promotion of BMS at health facilities [111].

Even though enforcing the most recent WHO guidelines and the WHO Code are necessary to improve breastfeeding outcomes in South Africa, they are not sufficient because as our review shows, there are additional barriers that impact breastfeeding outcomes, including lack of social support among women returning to work or school after the birth of their children.
Mixed-methods research, including in-depth interviews with key informants representing different government sectors and civil society is needed to prioritize actions and strategies to make this happen in South Africa. This effort should be followed by implementation research and policy instruments [112, 113] that can guide South Africa in its efforts to scale up the protection, promotion, and support of breastfeeding programs at the national level in the context of the HIV pandemic.

\section{Acknowledgements \\ Not applicable.}

\section{Authors' contributions}

RPE and DV conceived the idea for this research. KN designed the database search strategies and conducted all searches. DV and MVC conducted record reviews and data extraction. DV led the writing of the manuscript. MVC and RPE provided critical feedback and helped shape the analysis and manuscript. All authors read and approved the final manuscript.

Funding

No funding sources.

Availability of data and materials

Data sharing not applicable to this article as no datasets were generated or analyzed during the current study.

\section{Declarations}

Ethics approval and consent to participate

Not applicable.

Consent for publication

Not applicable.

Competing interests

The authors declare that they have no competing interests.

\section{Author details}

${ }^{1}$ Yale University School of Public Health, New Haven, CT 06510, USA. ${ }^{2}$ Yale University, Cushing/Whitney Medical Library, 333 Cedar St., New Haven, CT 06510, USA.

Received: 8 December 2020 Accepted: 1 April 2021

Published online: 04 May 2021

\section{References}

1. The DHS Program STATcompiler - South Africa [https://www.statcompiler. com/en/].

2. South Africa Demographic and Health Survey 2016: Key Indicators Report [http://www.statssa.gov.za/publications/Report\%2003-00-09/Report\%200300-092016.pdf].

3. World Development Indicators - South Africa [https://data.worldbank.org/ country/south-africa?view=chart].

4. Country Profile - South Africa [https://databank.worldbank.org/views/ reports/reportwidget.aspx?Report Name=CountryProfile\&ld=b450fd57\&tba $r=y \& d d=y \& i n f=n \& z m=n \&$ country=ZAF].

5. The World Factbook- South Africa [https://www.cia.gov/library/publications/ the-world-factbook/geos/sf.html].

6. Maternal mortality data: Trends in estimates of maternal mortality ratio (maternal deaths per 100,000 live births) 2000-2017 [https://data.unicef.org/ resources/dataset/maternal-mortality-data/\#].

7. Mortality rate, under-5 (per 1,000 live births) [https://data.worldbank.org/ indicator/SH.DYN.MORT?locations=ZG].

8. Mortality rate, infant (per 1,000 live births) [https://data.worldbank.org/indica tor/SP.DYN.IMRT.IN?locations=ZG].

9. Guideline: updates on HIV and infant feeding: the duration of breastfeeding, and support from health services to improve feeding practices among 
mothers living with HIV [https://apps.who.int/iris/bitstream/handle/10665/24 6260/9789241549707-eng.pdf? sequence=1].

10. Victora CG, Bahl R, Barros AJ, Franca GV, Horton S, Krasevec J, et al. Breastfeeding in the 21st century: epidemiology, mechanisms, and lifelong effect. Lancet. 2016;387(10017):475-90. https://doi.org/10.1016/50140-6736(1 5)01024-7.

11. Ogbo FA, Agho K, Ogeleka P, Woolfenden S, Page A, Eastwood J. Infant feeding practices and diarrhoea in sub-Saharan African countries with high diarrhoea mortality. PLoS One. 2017;12(2):e0171792. https://doi.org/10.1371/ journal.pone.0171792.

12. Yan J, Liu L, Zhu Y, Huang G, Wang PP. The association between breastfeeding and childhood obesity: a meta-analysis. BMC Public Health. 2014;14(1):1267. https://doi.org/10.1186/1471-2458-14-1267.

13. Rito Al, Buoncristiano M, Spinelli A, Salanave B, Kunešová M, Hejgaard T, et al. Association between characteristics at birth, breastfeeding and obesity in 22 countries: the WHO European childhood obesity surveillance initiative - COSI 2015/2017. Obes Facts. 2019;12(2):226-43. https://doi.org/10.1159/ 000500425 .

14. DHHS. Benefits of breastfeeding. Nutr Clin Care. 2003;6(3):125-31.

15. Del Ciampo LA, Del Ciampo IRL. Breastfeeding and the benefits of lactation for Women's health. Rev Bras Ginecol Obstet. 2018:40(6):354-9.

16. Sattari M, Serwint JR, Levine DM. Maternal implications of breastfeeding: a review for the internist. Am J Med. 2019;132(8):912-20. https://doi.org/10.1 016/j.amjmed.2019.02.021.

17. Driving commitment for nutrition within the UN Decade of Action on Nutrition: Policy Brief [https://apps.who.int/iris/bitstream/handle/10665/2743 75/WHO-NMH-NHD-17.11-eng.pdf?ua=1].

18. Implementation guidance: protecting, promoting and supporting breastfeeding in facilities providing maternity and newborn services - the revised Baby-friendly Hospital Initiative [https://apps.who.int/iris/bitstream/ handle/10665/272943/9789241513807-eng.pdf?ua=1].

19. Kuhn L, Aldrovandi G. Pendulum swings in HIV-1 and infant feeding policies: now halfway back. Adv Exp Med Biol. 2012;743:273-87. https://doi. org/10.1007/978-1-4614-2251-8_20.

20. MMWR. Achievements in public health. Reduction in perinatal transmission of HIV infection--United States, 1985-2005. MMWR Morb Mortal Wkly Rep. 2006, 55(21):592-7.

21. CDC. Recommendations for assisting in the prevention of perinatal transmission of human T-lymphotropic virus type III/lymphadenopathyassociated virus and acquired immunodeficiency syndrome. MMWR Morb Mortal Wkly Rep. 1985;34(48):721-6 731-722.

22. New data on the prevention of mother-to-child transmission of HIV and their policy implications: Conclusions and Recommendations [https:/apps. who.int/iris/bitstream/handle/10665/66851/WHO_RHR_01.28.pdf?sequence= 1\&isAllowed=y].

23. HIV and infant feeding: update based on the technical consultation held on behalf ofthe Inter-agency Team (IATT) on Prevention of HIV Infections in Pregnant Women,Mothers and their Infants, Geneva, 25-27 October 2006 [https://apps.who.int/iris/bitstream/handle/10665/43747/9789241595964 eng.pdf? sequence $=1$ \&isAllowed $=y]$.

24. Guidelines on HIV and infant feeding 2010: Principles and recommendations for infant feeding in the context of HIV and a summary of evidence [https://apps.who.int/iris/bitstream/handle/10665/44345/ 9789241599535_eng.pdf?sequence=1].

25. South-Africa-DOH. The Tshwane declaration of support for breastfeeding in South Africa. South Afr J Clin Nutr. 2011;24(4):214.

26. HIV and Infant Feeding 2010: An Updated Framework for Priority Action [https://apps.who.int/iris/bitstream/handle/10665/75152/FWC_MCA_12.1_ eng.pdf;jsessionid=38B65CED28E1E8B387DBBE4F71B61A58? sequence $=1]$.

27. Baby-friendly Hospital Initiative [https:/www.who.int/nutrition/topics/bfhi/en/]

28. The International Code of Marketing of Breast-Milk Substitutes - 2017 update: frequently asked questions [https://apps.who.int/iris/bitstream/ha ndle/10665/254911/WHO-NMH-NHD-17.1-eng.pdf? sequence=1].

29. International Code of Marketing of Breast-milk Substitutes [https://www. who.int/nutrition/publications/code_english.pdf].

30. McFadden A, Mason F, Baker J, Begin F, Dykes F, Grummer-Strawn L, et al. Spotlight on infant formula: coordinated global action needed. Lancet. 2016:387(10017):413-5, https://doi.org/10.1016/50140-6736(16)00103-3.

31. Robinson H, Buccini G, Curry L, Perez-Escamilla R. The World Health Organization code and exclusive breastfeeding in China, India, and Vietnam. Matern Child Nutr. 2019;15(1):e12685. https://doi.org/10.1111/mcn.12685.
32. Barennes $H$, Slesak $G$, Goyet $S$, Aaron $P$, Srour LM. Enforcing the international code of Marketing of Breast-milk Substitutes for better promotion of exclusive breastfeeding: can lessons be learned? J Hum Lact. 2016:32(1):20-7. https://doi.org/10.1177/0890334415607816.

33. Lake L, Kroon M, Sanders D, Goga A, Witten C, Swart R, et al. Child health, infant formula funding and south African health professionals: eliminating conflict of interest. S Afr Med J. 2019;109(12):902-6. https://doi.org/10.7196/ SAMJ.2019.v109i12.14336.

34. Baker P, Smith J, Salmon L, Friel S, Kent G, lellamo A, et al. Global trends and patterns of commercial milk-based formula sales: is an unprecedented infant and young child feeding transition underway? Public Health Nutr. 2016;19(14):2540-50. https://doi.org/10.1017/S1368980016001117.

35. Nieuwoudt SJ, Ngandu CB, Manderson L, Norris SA. Exclusive breastfeeding policy, practice and influences in South Africa, 1980 to 2018: a mixedmethods systematic review. PLoS One. 2019;14(10):e0224029. https://doi. org/10.1371/journal.pone.0224029.

36. Policy and guidlines for the implemention of the PMTCT programme [https://static.pmg.org.za/docs/080226pmtct.pdf].

37. Peters MD, Godfrey C, Mclnerney P, Munn Z, Tricco AC, Khalil H. Scoping Reviews (2020 version). In: Aromataris E, Munn Z, editors. Joanna Briggs Institute Reviewer's Manual: JBI; 2020

38. Tricco AC, Lillie E, Zarin W, O'Brien KK, Colquhoun H, Levac D, et al. PRISMA extension for scoping reviews (PRISMA-ScR): checklist and explanation. Ann Intern Med. 2018;169(7):467-73. https://doi.org/10.7326/M18-0850.

39. McGowan J, Sampson M, Salzwedel DM, Cogo E, Foerster V, Lefebvre C. PRESS Peer Review of Electronic Search Strategies: 2015 Guideline Statement. J Clin Epidemiol. 2016, 75:40-6.

40. Covidence [https://www.covidence.org/].

41. Doherty T, Chopra M, Nkonki L, Jackson D, Persson L-A. A longitudinal qualitative study of infant-feeding decision making and practices among HIV-positive women in South Africa. J Nutr. 2006;136(9):2421-6. https://doi. org/10.1093/jn/136.9.2421.

42. Andreson J, Dana N, Hepfer B, King'ori E, Oketch J, Wojnar D, et al. Infant feeding buddies: a strategy to support safe infant feeding for HIV-positive mothers. J Hum Lact. 2013;29(1):90-3. https://doi.org/10.1177/08903344124 69056.

43. Ladzani R, Peltzer K, Mlambo MG, Phaweni K. Infant-feeding practices and associated factors of HIV-positive mothers at Gert Sibande, South Africa. Acta paediatrica (Oslo, Norway : 1992). 2011;100(4):538-42.

44. Doherty T, Chopra M, Jackson D, Goga A, Colvin M, Persson L-A. Effectiveness of the WHO/UNICEF guidelines on infant feeding for HIVpositive women: results from a prospective cohort study in South Africa. AIDS (London, England). 2007;21(13):1791-7.

45. Cournil A, De Vincenzi I, Gaillard P, Cames C, Fao P, Luchters S, et al. Relationship between mortality and feeding modality among children born to HIV-infected mothers in a research setting: the Kesho Bora study. AIDS (London, England). 2013;27(10):1621-30.

46. Bork K, Cames C, Cournil A, Musyoka F, Ayassou K, Naidu K, et al. Infant feeding modes and determinants among HIV-1-infected African Women in the Kesho Bora Study. J Acquir Immune Defic Syndr (1999). 2013;62(1):109-18.

47. Ramokolo V, Lombard C, Chhagan M, Engebretsen IM, Doherty T, Goga AE, et al. Effects of early feeding on growth velocity and overweight/obesity in a cohort of HIV unexposed south African infants and children. Int Breastfeed J. 2015;10(101251562):14. https://doi.org/10.1186/s13006-015-0041-x.

48. Goga AE, Van Wyk B, Doherty T, Colvin M, Jackson DJ, Chopra M. Good Start Study G: Operational effectiveness of guidelines on complete breast-feeding cessation to reduce mother-to-child transmission of HIV: results from a prospective observational cohort study at routine prevention of mother-tochild transmission sites, South Africa. J Acquir Immune Defic Syndr (1999). 2009:50(5):521-8

49. Bland RM, Little KE, Coovadia HM, Coutsoudis A, Rollins NC, Newell M-L. Intervention to promote exclusive breast-feeding for the first 6 months of life in a high HIV prevalence area. AIDS (London, England). 2008;22(7):883-91.

50. Rossouw ME, Cornell M, Cotton MF, Esser MM. Feeding practices and nutritional status of HIV-exposed and HIV-unexposed infants in the Western cape. Southern African journal of HIV medicine. 2016;17(1):398. https://doi. org/10.4102/sajhivmed.v17i1.398.

51. Aku A. The influence of maternal socio-economic status on infant feeding practices and anthropometry of HIV-exposed infants; 2013.

52. Masters DP. Beliefs and practices of mothers living with HIV/AIDS regarding infant feeding; 2006 
53. Some EN, Engebretsen IMS, Nagot N, Meda N, Lombard C, Vallo R, et al. Breastfeeding patterns and its determinants among mothers living with Human Immuno-deficiency Virus-1 in four African countries participating in the ANRS 12174 trial. Int Breastfeed J. 2017;12(22). https://doi.org/10.1186/ s13006-017-0112-2.

54. Doherty T, Chopra M, Nkonki L, Jackson D, Greiner T. Effect of the HIV epidemic on infant feeding in South Africa: "when they see me coming with the tins they laugh at me". Bull World Health Organ. 2006;84(2):90-6. https://doi.org/10.2471/BLT.04.019448.

55. Sibeko L, Coutsoudis A, Sp N, Gray-Donald K. Mothers' infant feeding experiences: constraints and supports for optimal feeding in an HIVimpacted urban community in South Africa. Public Health Nutr. 2009;12(11): 1983-90. https://doi.org/10.1017/\$1368980009005199.

56. Chetty T, Carter RJ, Bland RM, Newell M-L. HIV status, breastfeeding modality at 5 months and postpartum maternal weight changes over 24 months in rural South Africa. Trop Med Int Health. 2014;19(7):852-62. https://doi.org/10.1111/tmi.12320

57. Matji JN, Wittenberg DF, Makin JD, Jeffery B, Maclntyre UE, Forsyth BWC. Factors affecting HIV-infected mothers' ability to adhere to antenatally intended infant feeding choice in Tshwane. SAJCH South Afr J Child Health. 2009;3(1):20-3.

58. Rollins NC, Ndirangu J, Bland RM, Coutsoudis A, Coovadia HM, Newell M-L. Exclusive breastfeeding, diarrhoeal morbidity and all-cause mortality in infants of HIV-infected and HIV uninfected mothers: an intervention cohort study in KwaZulu Natal, South Africa. PloS one. 2013;8(12):e81307. https:// doi.org/10.1371/journal.pone.0081307.

59. Ahmadu-Ali UA, Couper ID. The practice of exclusive breastfeeding among mothers attending a postnatal clinic in Tswaing subdistrict, north West province. S Afr Fam Pract. 2013;55(4):385-90. https://doi.org/10.1080/207862 04.2013.10874381.

60. Faber M, Benade AJS. Breastfeeding, complementary feeding and nutritional status of 6-12-month-old infants in rural KwaZulu-Natal. South Afr J Clin Nutr. 2007;20(1):16-24.

61. Patil CL, Turab A, Ambikapathi R, Nesamvuni C, Chandyo RK, Bose A, et al. Early interruption of exclusive breastfeeding: results from the eight-country MAL-ED study. J Health Popul Nutr. 2015;34(100959228, dtt):10.

62. Kyei KA, Netshikweta ML, Spio K. Breastfeeding in the Vhembe district of Limpopo Province, South Africa: duration and factors. Stud Ethno-Medicine. 2014;8(3):317-24. https://doi.org/10.1080/09735070.2014.11917648.

63. Gbadamosi MA, Goon DT, Tugli A. Relationship between feeding practices and patterns of infant growth: a cross-sectional study. Re J Med Sci. 2017; 11(4):166-73.

64. West NS, Schwartz SR, Yende N, Schwartz SJ, Parmley L, Gadarowski MB, et al. Infant feeding by south African mothers living with HIV: implications for future training of health care workers and the need for consistent counseling. Int Breastfeed J. 2019;14(101251562):11. https://doi.org/10.1186/ s13006-019-0205-1.

65. Budree S, Goddard E, Brittain K, Cader S, Myer L, Zar HJ. Infant feeding practices in a South African birth cohort-A longitudinal study. Matern Child Nutr 2017;13(3). https://doi.org/10.1111/mcn.12371.

66. le Roux SM, Abrams EJ, Donald KA, Brittain K, Phillips TK, Zerbe A, et al. Infectious morbidity of breastfed, HIV-exposed uninfected infants under conditions of universal antiretroviral therapy in South Africa: a prospective cohort study. Lancet Child Adolesc Health. 2020;4(3):220-31. https://doi. org/10.1016/S2352-4642(19)30375-X.

67. Tchakoute CT, Sainani KL, Osawe S, Datong P, Kiravu A, Rosenthal KL, et al. Breastfeeding mitigates the effects of maternal HIV on infant infectious morbidity in the Option B+ era. AIDS (London, England). 2018;32(16):2383-91.

68. Remmert JE, Mosery N, Goodman G, Bangsberg DR, Safren SA, Smit JA, et al. Breastfeeding practices among women living with HIV in KwaZulu-Natal, South Africa: an observational study. Matern Child Health J. 2020;24(2):12734. https://doi.org/10.1007/s10995-019-02848-8.

69. Nieuwoudt S, Manderson L, Norris SA. Infant feeding practices in Soweto, South Africa: implications for healthcare providers. S Afr Med J. 2018;108(9): 756-62. https://doi.org/10.7196/SAMJ.2018.v108i9.13358.

70. Motadi SA. Breastfeeding knowledge and practices among mothers of children younger than 2 years from a rural area in the Limpopo Province, South Africa. SAJCH S Afr J Child Health. 2019;13(3):115-9. https://doi.org/1 0.7196/SAJCH.2019.v13i3.1570.

71. Siziba LP. Feeding practices of mothers and/or caregivers of infants below the age of 6 months in South Africa; 2014.
72. Mushaphi LF, Mahopo TC, Nesamvuni CN, Baloyi B, Mashau E, Richardson J, et al. Recommendations for infant feeding policy and programs in Dzimauli region, South Africa: results from the MAL-ED birth cohort. Food Nutr Bull. 2017;38(3):428-40. https://doi.org/10.1177/0379572117696662.

73. Goosen C, McLachlan MH, Schubl C. Infant feeding practices during the first 6 months of life in a low-income area of the Western Cape Province. SAJCH S Afr J Child Health. 2014;8(2):50-4. https://doi.org/10.7196/sajch.675.

74. Kennedy YP. An assessment of infant feeding knowledge, attitude and intended practice of women delivering at Chris Hani Baragwanath hospital. Dissertation. 2016.

75. Matsungo TM, Kruger HS, Faber M, Rothman M, Smuts CM. The prevalence and factors associated with stunting among infants aged 6 months in a peri-urban south African community. Public Health Nutr. 2017;20(17):320918. https://doi.org/10.1017/\$1368980017002087.

76. Chakona G. Social circumstances and cultural beliefs influence maternal nutrition, breastfeeding and child feeding practices in South Africa. Nutr J. 2020;19(1):47. https://doi.org/10.1186/s12937-020-00566-4.

77. Jama NA, Wilford A, Masango Z, Haskins L, Coutsoudis A, Spies L, et al. Enablers and barriers to success among mothers planning to exclusively breastfeed for six months: a qualitative prospective cohort study in KwaZulu-Natal, South Africa. Int Breastfeed J. 2017;12(101251562):43. https:// doi.org/10.1186/s13006-017-0135-8.

78. Horwood C, Haskins L, Engebretsen IM, Phakathi S, Connolly C, Coutsoudis A, et al. Improved rates of exclusive breastfeeding at 14 weeks of age in KwaZulu Natal, South Africa: what are the challenges now? BMC Public Health. 2018;18(1):757. https://doi.org/10.1186/s12889-018-5657-5.

79. Madiba S. Factors associated with mixed feeding practices among HIV positive post-natal women in Merafong sub-district, Gauteng Province, South Africa: public health intervention for maternal and child health. Special Issue. 2015;21(Suppl. 2.1):25-38.

80. Siziba LP, Jerling J, Hanekom SM, Wentzel-Viljoen E. Low rates of exclusive breastfeeding are still evident in four south African provinces. S Afr J Clin Nutr. 2015;28(4):170-9. https://doi.org/10.1080/16070658.2015.11734557.

81. Bork KA, Cournil A, Read JS, Newell M-L, Cames C, Meda N, et al. Morbidity in relation to feeding mode in African HIV-exposed, uninfected infants during the first 6 mo of life: the Kesho bora study. Am J Clin Nutr. 2014; 100(6):1559-68. https://doi.org/10.3945/ajcn.113.082149.

82. KeshoBora-Study-Group. Safety and effectiveness of antiretroviral drugs during pregnancy, delivery and breastfeeding for prevention of mother-to-child transmission of HIV-1: the Kesho Bora Multicentre Collaborative Study rationale, design, and implementation challenges. Contemp Clin Trials. 2011;32(1):74-85.

83. Tylleskar T, Jackson D, Meda N, Engebretsen IM, Chopra M, Diallo AH, et al. Exclusive breastfeeding promotion by peer counsellors in sub-Saharan Africa (PROMISE-EBF): a cluster-randomised trial. Lancet. 2011;378(9789):4207. https://doi.org/10.1016/S0140-6736(11)60738-1.

84. Doherty T, Jackson D, Swanevelder S, Lombard C, Engebretsen IMS, Tylleskar T, et al. Severe events in the first 6 months of life in a cohort of HIVunexposed infants from South Africa: effects of low birthweight and breastfeeding status. Trop Med Int Health. 2014;19(10):1162-9. https://doi. org/10.1111/tmi.12355

85. Doherty T, Sanders D, Jackson D, Swanevelder S, Lombard C, Zembe W et al. Early cessation of breastfeeding amongst women in South Africa: an area needing urgent attention to improve child health. BMC Pediatr. 2012; 12(100967804):105. https://doi.org/10.1186/1471-2431-12-105.

86. Engebretsen IMS, Nankabirwa V, Doherty T, Diallo AH, Nankunda J, Fadnes LT, et al. Early infant feeding practices in three African countries: the PROMISE-EBF trial promoting exclusive breastfeeding by peer counsellors. Int Breastfeed J. 2014;9(101251562):19. https://doi.org/10.1186/1746-4358-9-19.

87. Guidelines to Industry and health care personnel: The regulations relating to foodstufs for infants and young children [file:///C:/Users/dv334/ Downloads/GuidelinesIndustry.pdf].

88. Foodstufs, cosmetics \& disinfectants Act, 1972 (Act 54 of 1972) [http://blogs sun.ac.za/iplaw/files/2013/12/ZAF-2012-Regulations-relating-to-foodstuffsfor-infants-and-young-children-R.-No.-991-of-2012_0.pdf].

89. Muravha N. Violations of the international code of Marketing of Breast Milk Substitutes in south African health facilities; 2014.

90. Radebe P. Assessing the extent of violations of the international code of Marketing of Breast Milk Substitutes in south African advertising media; 2014.

91. Anttila-Hughes JK, Fernald LCH, Gertler PJ, Krause P, Wydick B. Mortality from Nestlé's Marketing of Infant Formula in low and middle income countries. In. Cambridge, MA: National Bureau of Economic Research; 2018. 
92. ljumba P, Doherty $T$, Jackson D, Tomlinson M, Sanders D, Persson LA. Free formula milk in the prevention of mother-to-child transmission programme: voices of a peri-urban community in South Africa on policy change. Health Policy Plan. 2013;28(7):761-8. https://doi.org/10.1093/heapol/czs114.

93. National consolidated guidelines for the prevention of mother-to-child transmission of HIV (PMTCT) and the management of HIV in children, adolescents and adults [https://sahivsoc.org/Files/ART\%20Guidelines\%201 5052015.pdf].

94. Larsen A, Magasana V, Dinh TH, Ngandu N, Lombard C, Cheyip M, et al. Longitudinal adherence to maternal antiretroviral therapy and infant Nevirapine prophylaxis from 6 weeks to 18 months postpartum amongst a cohort of mothers and infants in South Africa. BMC Infect Dis. 2019;19(Suppl 1):789. https://doi.org/10.1186/s12879-019-4341-4.

95. Country Report, South Africa: Overview 2018 [https://www.unaids.org/en/ regionscountries/countries/southafrica].

96. Country progress report - South Africa: Global AIDS Monitoring 2018 [https://www.unaids.org/sites/default/files/country/documents/ZAF_2018_ countryreport.pdf]

97. Rollins NC, Bhandari N, Hajeebhoy N, Horton S, Lutter CK, Martines JC, et al. Why invest, and what it will take to improve breastfeeding practices? Lancet. 2016;387(10017):491-504. https://doi.org/10.1016/S0140-6736(15)01 044-2.

98. Carroll G, Atuobi-Yeboah A, Hromi-Fiedler A, Aryeetey R, Safon C, PérezEscamilla R. Factors influencing the implementation of the becoming breastfeeding friendly initiative in Ghana. Matern Child Nutr. 2019;15(3): e12787. https://doi.org/10.1111/mcn.12787.

99. González de Cosío T, Ferré I, Mazariegos M, Pérez-Escamilla R. Scaling Up Breastfeeding Programs in Mexico: Lessons Learned from the Becoming Breastfeeding Friendly Initiative. Curr Dev Nutr. 2018;2(6):nzy018.

100. Than MK, Nyi SN, Hlaing LM, Mar SL, Thwin T, Cashin J, et al. Scaling Up Breastfeeding in Myanmar through the Becoming Breastfeeding Friendly Initiative. Curr Dev Nutr. 2019;3(8):nzz078.

101. Soti-Ulberg C, Hromi-Fiedler A, Hawley NL, Naseri T, Manuele-Magele A, AhChing J, et al. Scaling up breastfeeding policy and programs in Samoa: application of the becoming breastfeeding friendly initiative. Int Breastfeed J. 2020;15(1):1. https://doi.org/10.1186/s13006-019-0245-6.

102. Horwood C, Jama NA, Haskins L, Coutsoudis A, Spies L. A qualitative study exploring infant feeding decision-making between birth and 6 months among HIV-positive mothers. Matern Child Nutr. 2019;15(2):e12726. https:// doi.org/10.1111/mcn.12726.

103. Chaponda A, Goon DT, Hoque ME. Infant feeding practices among HIVpositive mothers at Tembisa hospital, South Africa. Afr J Prim Health Care Fam Med. 2017;9(1):e1-6. https://doi.org/10.4102/phcfm.v9i1.1278.

104. ljumba $P$, Doherty $T$, Jackson D, Tomlinson M, Sanders D, Swanevelder S, et al. Effect of an integrated community-based package for maternal and newborn care on feeding patterns during the first 12 weeks of life: a cluster-randomized trial in a south African township. Public Health Nutr. 2015;18(14):2660-8. https://doi.org/10.1017/S1368980015000099.

105. Zulliger R, Abrams EJ, Myer L. Diversity of influences on infant feeding strategies in women living with HIV in Cape Town, South Africa: a mixed methods study. Trop Med Int Health. 2013;18(12):1547-54. https://doi.org/1 $0.1111 /$ tmi.12212.

106. Pérez-Escamilla R, Curry L, Minhas D, Taylor L, Bradley E. Scaling up of breastfeeding promotion programs in low- and middle-income countries: the "breastfeeding gear" model. Adv Nutr. 2012;3(6):790-800. https://doi. org/10.3945/an.112.002873.

107. Foodstuffs, Cosmetics and Disinfeefants Act 1972 [https://www.gov.za/sites/ default/files/gcis_document/201504/act-54-1972.pdf].

108. Clarke M, Koen N, du Plessis L. Perspectives from south African dietitians on infant and young child feeding regulations. Public Health Nutr. 2021;24(1): 169-81. https://doi.org/10.1017/S1368980020000233.

109. Zunza M, Esser M, Slogrove A, Bettinger JA, Machekano R, Cotton MF. Early breastfeeding cessation among HIV-infected and HIV-uninfected women in Western Cape Province, South Africa. AIDS Behav. 2018;22(Suppl 1):114-20. https://doi.org/10.1007/s10461-018-2208-0.

110. Jackson D, Swanevelder S, Doherty T, Lombard C, Bhardwaj S, Goga A. Changes in rates of early exclusive breast feeding in South Africa from 2010 to 2013: data from three national surveys before and during implementation of a change in national breastfeeding policy. BMJ Open. 2019:9(11):e028095. https://doi.org/10.1136/bmjopen-2018-028095.
111. Marketing of breast-milk substitutes: national implementation of the international code, status report 2020 [file:///C:/Users/dv334/AppData/Local/ Temp/1/9789240006010-eng.pdf].

112. Pérez-Escamilla R, Hromi-Fiedler AJ, Gubert MB, Doucet K, Meyers S, Dos Santos BG. Becoming breastfeeding friendly index: development and application for scaling-up breastfeeding programmes globally. Matern Child Nutr. 2018;14(3):e12596. https://doi.org/10.1111/mcn.12596.

113. Hromi-Fiedler AJ, Dos Santos BG, Gubert MB, Doucet K, Pérez-Escamilla R. Development and pretesting of "becoming breastfeeding friendly": empowering governments for global scaling up of breastfeeding programmes. Matern Child Nutr. 2019;15(1):e12659. https://doi.org/10.1111/ mcn.12659.

\section{Publisher's Note}

Springer Nature remains neutral with regard to jurisdictional claims in published maps and institutional affiliations.
Ready to submit your research? Choose BMC and benefit from:

- fast, convenient online submission

- thorough peer review by experienced researchers in your field

- rapid publication on acceptance

- support for research data, including large and complex data types

- gold Open Access which fosters wider collaboration and increased citations

- maximum visibility for your research: over $100 \mathrm{M}$ website views per year

At $\mathrm{BMC}$, research is always in progress.

Learn more biomedcentral.com/submissions 